\title{
ORIGINAL ARTICLE \\ Effect of tree characteristics on roost selection of the Indian flying fox, Pteropus giganteus
}

\author{
Ram Kumar ${ }^{1} \&$ Vadamalai Elangovan $^{1, *}$
}

\author{
${ }^{1}$ Department of Applied Animal Sciences, \\ Babasaheb Bhimrao Ambedkar University, \\ Lucknow-226025, Uttar Pradesh, India \\ *Corresponding author: \\ elango70@yahoo.com \\ DOI: https://doi.org/10.14709/ \\ BarbJ.12.1.2019.13 \\ Keywords: Colony size, distribution, \\ Pteropus giganteus, roost tree \\ characteristics, roost selection \\ received: December, 18th 2018 \\ accepted: December, 13rd 2019
}

\begin{abstract}
Tree characteristics are critical in determining roost quality for bats. Roosts are vital for the survival, social interaction, reproduction of a species, however optimum roost characteristics are poorly understood for several pteropodid species. In this study we aimed to improve our understanding of roost selection by the gregarious roosting species, the Indian flying fox, Pteropus giganteus. 72 colonies of $P$. giganteus were studied to assess the impact of roost traits such as diameter at breast height (dbh), tree height and canopy spread and non-roost dependent factors such as distance of roost from adjacent roads, water bodies and human settlements. The impact of relative grove size was also investigated. The characteristics of roost trees were compared with non-roost trees in order to quantify roost preference and selection. We identified the average colony size as $497.3 \pm 270.0$ individuals in Uttar Pradesh. At least 435 trees were used as roosts, which belonged to 22 tree species. The selection of roost trees was highly influenced by tree $\mathrm{dbh}$, followed by canopy spread and tree height ( $r=0.214)$. Most of non-roost dependent factors (i.e. distance of roosts from adjacent roads, human settlements and waterbodies) did not influence roost selection, however grove size and the number of potential roost trees was positively correlated with colony size. Thus, this study indicates protecting large trees and large groves would benefit the conservation of $P$. giganteus.
\end{abstract}

\section{INTRODUCTION}

The Indian flying fox, Pteropus giganteus (Brunnich 1782), is common and widely distributed across India, Pakistan, Nepal, Bangladesh, Bhutan, China, Maldives, Myanmar and Sri Lanka (Molur et al. 2008). Individuals of $P$. giganteus live gregariously in well-exposed large trees, and camp size ranges from a few hundred to many thousands (Eby 1991, Parry-Jones \& Augee 1992, Markus \& Blackshaw 2002). Day roosts offer a site for courtship, social activity and mother-infant interaction (Markus \& Blackshaw 2002). These exchanges among individuals influence group social structure and mating systems (Kunz \& Lumsden 2003).

Marimuthu (1988) reported that $P$. giganteus is considered as sacred species within a few villages across southern and northern India. Flying foxes are eco-enhancers that effectively improve the ecosystem by seed dispersal and pollination services (Fujita \& Tuttle 1991). They play a vital role in seed dispersal by retaining viable seeds in their guts during different foraging flights and defecate while returning to their diurnal roosts (Shilton et al. 1999). However, they face a number of anthropogenic threats, of which hunting for bushmeat and felling of roost trees are the major contributors (Neupane et al. 2016).
Roost selection is a subset of habitat selection which influences the survival and reproduction of animals. As treeroosting bats, $P$. giganteus spend about half of their lifespan at their day roosts, and the selection of roost trees plays a vital role in their survival. Roost sites are critical for population persistence, offspring development, social interaction and reproduction (Kerth et al. 2003). The selection of roost trees is determined on the desirability of specific tree characteristics. Kalcounis-Ruppell et al. (2005) found that tree-roosting bats choose tall trees with a large diameter at breast height (dbh). Very little information is known on the habitat characteristics, selection and utilization by Acerodon jubatus, Pteropus livingstonii, $P$. vampyrus lanensis and $P$. giganteus (Granek 2002, Mildenstein et al. 2005, Hahn et al. 2014, Gulraiz et al. 2015), and no species-specific information is available for $P$. giganteus. Therefore, we have tried to elucidate the relationship between roost tree characteristics and roost selection of $P$. giganteus. We predict roost tree characteristics significantly influence roost selection and also that optimum tree characteristics accommodate higher densities of bats than suboptimal roosts.

\section{MATERIALS AND METHODS}

This study was carried out between August 2012 and December 2015 in rural, semi-urban and urban areas of Uttar Pradesh, India (Fig. 1). The temperature and relative 


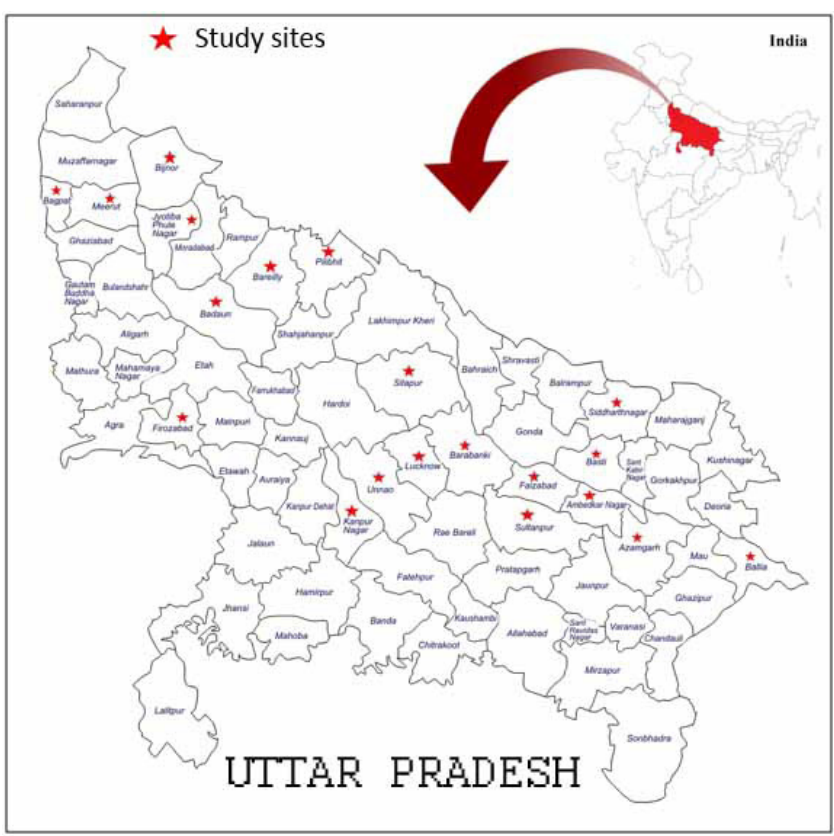

Fig. 1 - Map of Uttar Pradesh, India. The districts which harbour Pteropus giganteus are marked with asterisks. More details are given in Table 1.

humidity of Uttar Pradesh range from $-1{ }^{\circ} \mathrm{C}$ to $47^{\circ} \mathrm{C}$, and $20 \%$ to $85 \%$, respectively. A list of the 72 colonies of $P$. giganteus observed in the study is provided with their corresponding GPS locations in Table 1. Characteristics of roosting and nonroosting trees were measured following Leverett \& Bertolette (2015). The diameter at breast height (dbh) was measured at approximately chest height or 4.5 feet above tree base. The $\mathrm{dbh}$ was obtained by dividing the circumference of tree by 3.141. The average of the widest span and the width of the crown at 90 degrees off is considered as canopy spread and was measured following the American forests champion trees measuring guidelines handbook (2014).

Tree height was measured by using the 'stick method', in which the observer held a ruler vertically at arm's length and moved forward or backward from the tree until part of the ruler from the top of hand covers the tree. The distance between the eye and top of the observer's hand was measured (a) and the length of ruler above the hand was measured (b). Thereafter, the distance between the observer and the base of tree was measured using a tape (A). The following formula was used to compute the tree height (B) from the values of (a), (b), (A): Tree height (B) $=\frac{a}{A} b$. This method incurred no financial burden and convenient in the field.

In addition, unoccupied large and tall trees with a wide canopy (dbh $>39.7 \mathrm{~cm}$, tree height $>10.1 \mathrm{~m}$, and canopy spread $>12.7 \mathrm{~m}$ ) located in the vicinity of roost trees were considered as non-roost trees. A specific group of trees was considered as grove. The non-roost dependent factors such as distance of roost from the adjacent roads, human settlements and waterbodies were also recorded using an odometer. Colony sizes were estimated by visual counts at the roost, following Kunz (1988) and Barlow (1999). A group of bats roosting in one or more trees at a specific place and time was considered a "colony" and the sum of individuals of all colonies was considered the "population". Utmost care was taken whilst counting the bats at the roost and the counting was conducted during midday when most of the bats were resting.

The tree characteristics of roost and non-roost trees were compared using an unpaired ' $\mathrm{t}$ ' test. Multiple regression analysis was performed with the colony size as the dependent factor and roost tree characteristics (such as $\mathrm{dbh}$, tree height and canopy spread) as independent factors using KyPlot, Version 2.0. Similarly, the effect of non-roost tree dependent factors such as distances to adjacent road, human settlement, and water source on colony size was analyzed using a multiple regression. The mean values are given with \pm SD throughout the text.

\section{RESULTS}

A total of 72 colonies comprising 35,808 individuals were observed in twenty districts of Uttar Pradesh, India (Table 1). A total of 435 trees belonging to 22 species and 16 genera were used by $P$. giganteus as roost trees (Fig. 2). Pteropus giganteus occupied preferably wide-canopy trees $(71.4 \%$ trees) such as $F$. benghalensis, $F$. racemosa, $F$. religiosa, $F$. virens, $M$. indica, S. cumini, B. latifolia, D. sissoo, D. regia and $A$. indica, while they occupied narrow-canopy trees in lower proportion ( $28.6 \%$ trees) like $T$. arjuna and $P$. longifolia.

Colony size ranged from 106 to 1250 individuals with an average of $497.3 \pm 270$. The mean number of roost trees used by a colony was $6.0 \pm 2.6$ and varied according to tree characteristics and grove size. $P$. giganteus seldom roosts in a lone tree, instead the colonies were observed in groves with a large number of trees. The average number of trees observed in a grove was $28.4 \pm 20.5$. The larger groves offered more roost trees to $P$. giganteus than the smaller groves ( $r=0.600$, Fig. 3c), and colony size increased with number of roost trees $(r=0.831$, Fig. 3a). Thus, the colony size of $P$. giganteus was influenced by grove size ( $r=0.629$, Fig. 3b). The average distance of roosts from adjacent roads, waterbodies and human settlements were $272 \pm 240 \mathrm{~m}, 158 \pm 183 \mathrm{~m}$, and $302 \pm 182 \mathrm{~m}$, respectively. The multiple regression analysis showed a positive effect of grove size $(r=0.516)$ and number of roost trees ( $r=$ 0.831 ) on colony size, however, there was no influence of the distance from human settlements $(r=0.073)$, road ( $r=$ $0.080)$ and waterbodies ( $r=-0.003$ ) on colony size. The roost tree dependent characteristics such as dbh, tree height and canopy spread varied among tree species. The average $\mathrm{dbh}$, tree height and canopy spread of roost trees were $60.6 \pm$ $16.4 \mathrm{~cm}, 15.4 \pm 2.7 \mathrm{~m}$ and $21.7 \pm 6.4 \mathrm{~m}$, respectively. The results of multiple regression showed that the selection of roost tree was influenced by the tree dbh ( $r=0.883$; Fig. 4a), height ( $r=0.214$; Fig. 4b) and canopy spread ( $r=0.669$; Fig. $4 c)$. Further, the tree characteristics between roosting and non-roosting trees such as $\mathrm{dbh}(t=7.73 ; P<0.001 ; d f=119)$, tree height $(t=8.29 ; P<0.001 ; d f=119)$ and canopy spread $(t=4.57, P<0.001, d f=119)$ differed significantly. 


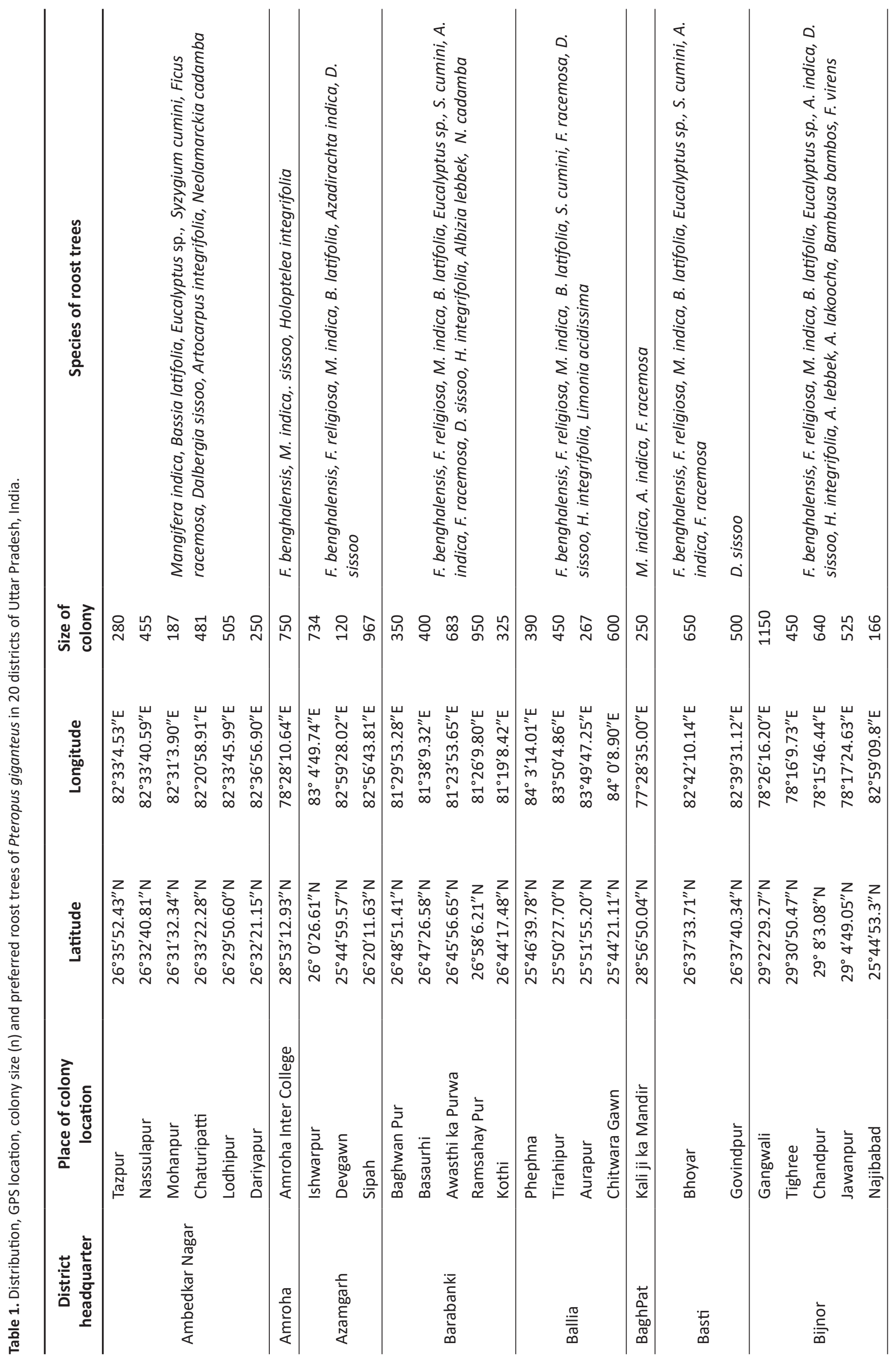




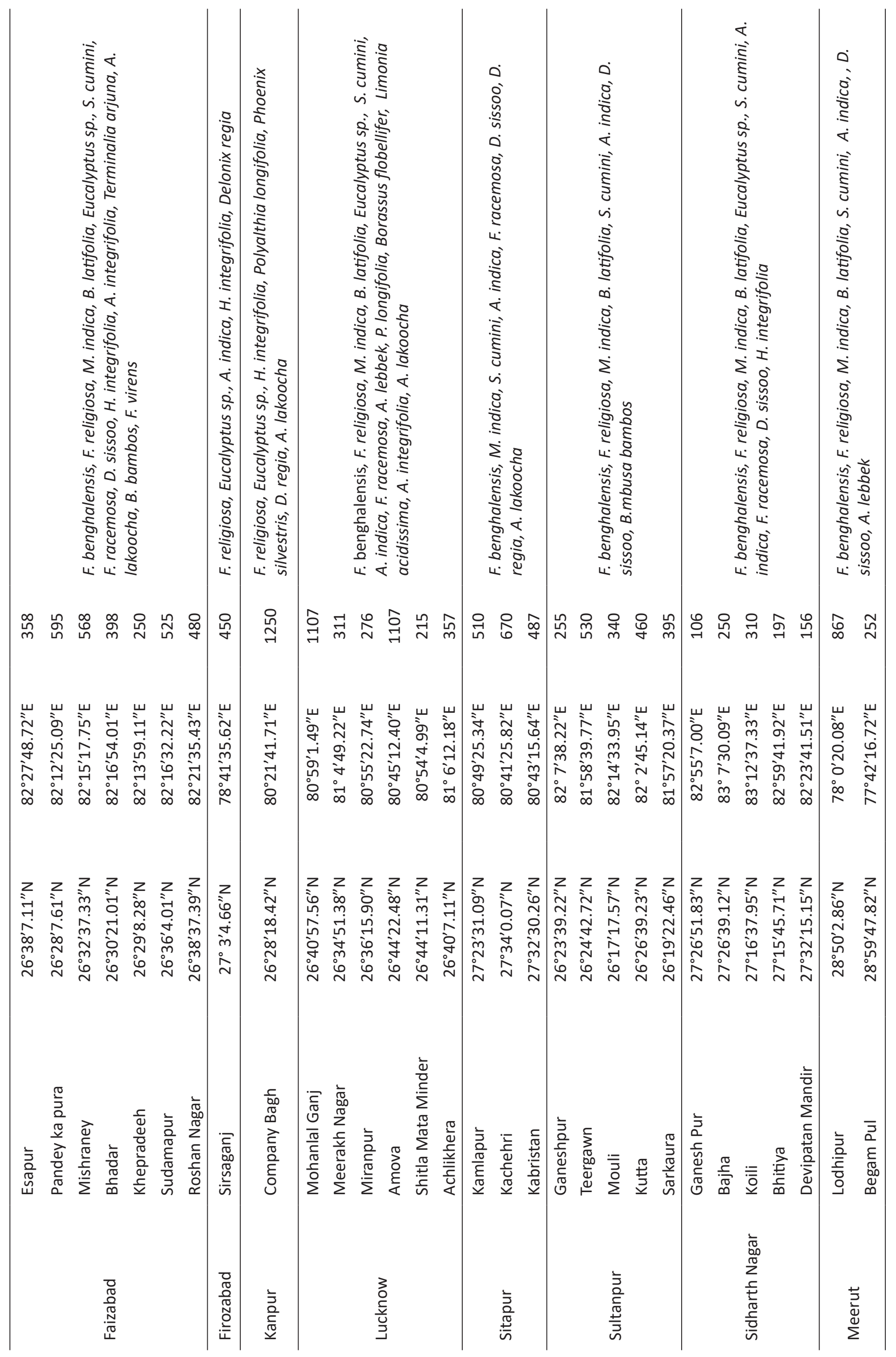




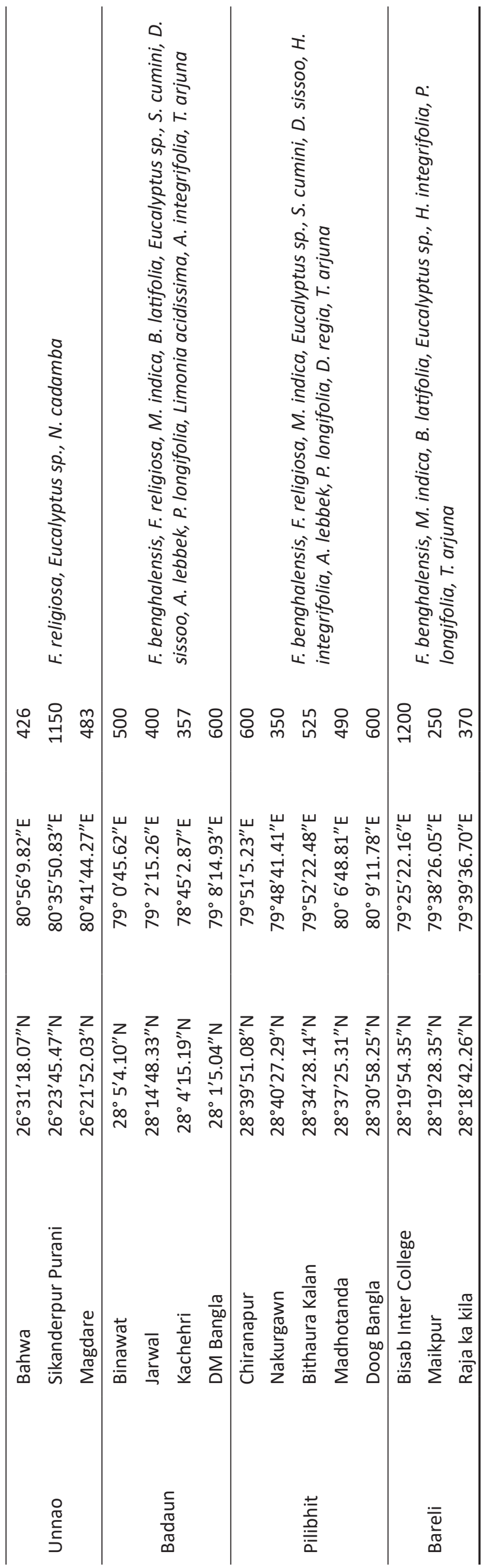

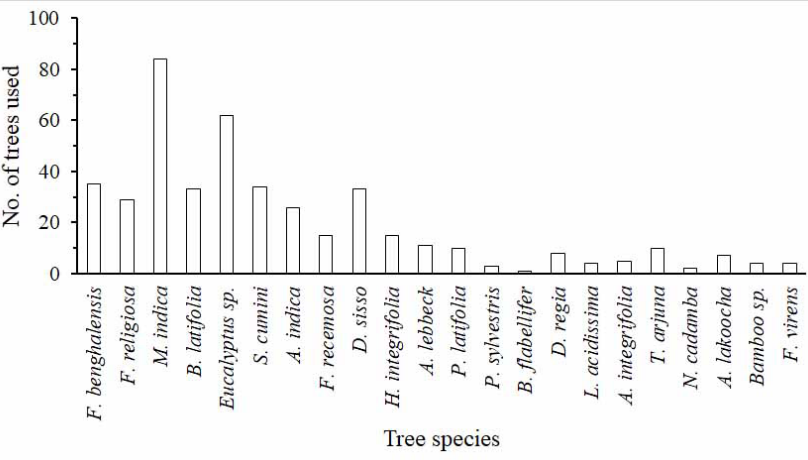

Fig. 2 - 22 tree species used by Pteropus giganteus as roost trees in Uttar Pradesh.
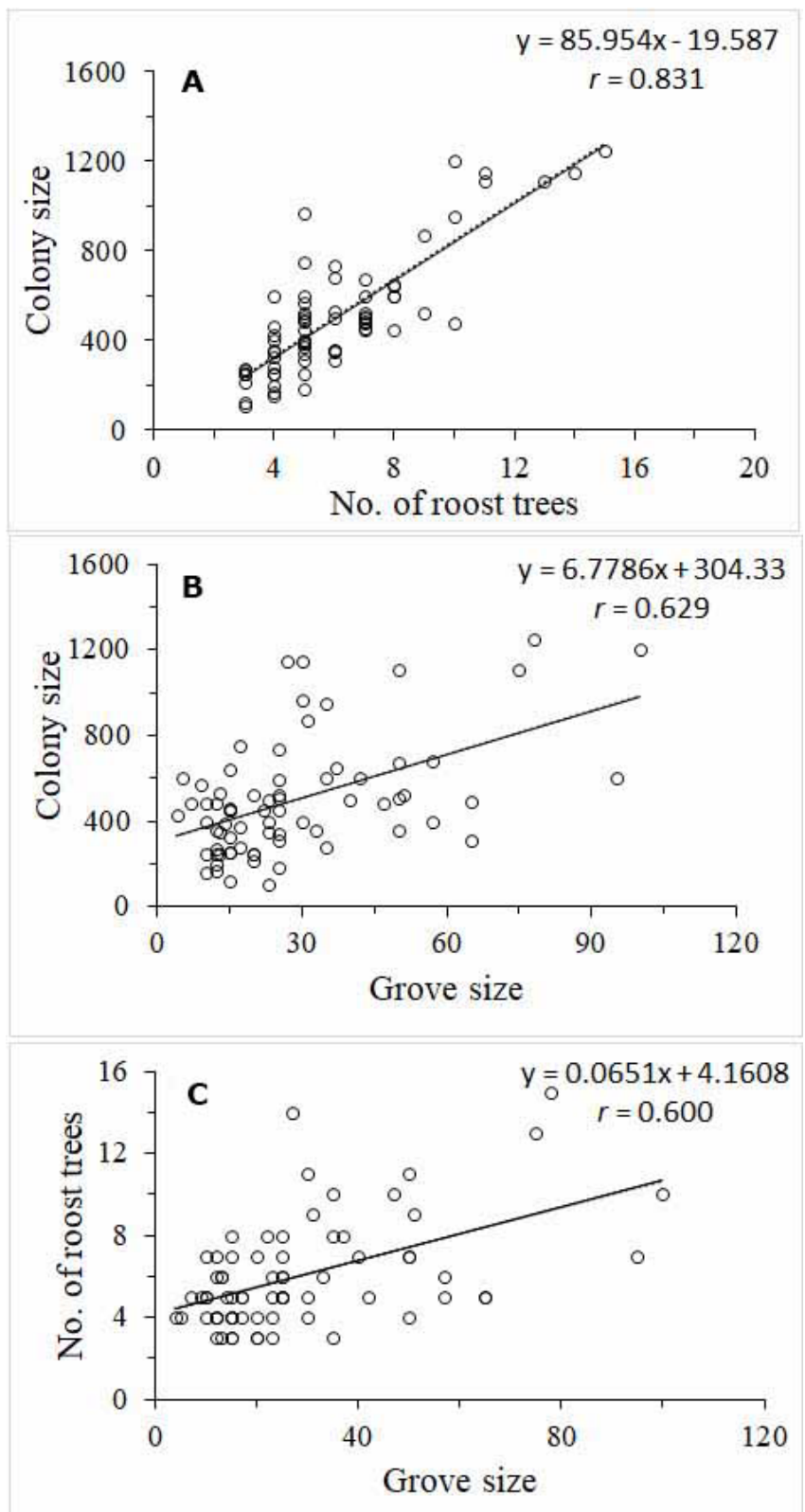

Fig. 3 - Relation between the colony size of Pteropus giganteus and A) number of roost trees, B) grove size and C) relation between grove size and number of roost trees. 

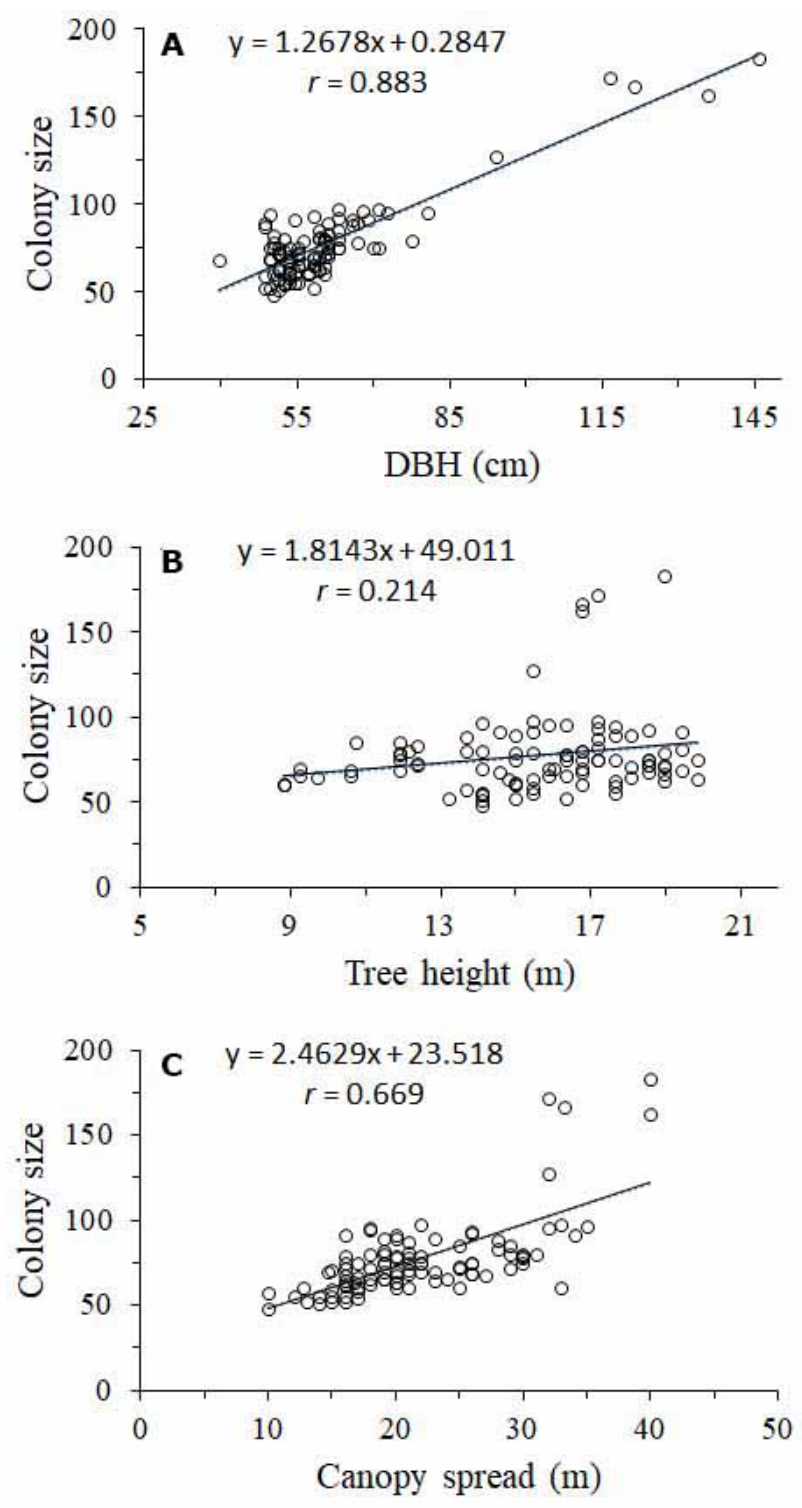

Fig. 4 Effect of roost tree characteristics A) dbh, B) height and C) canopy spread on the colony size of Pteropus giganteus.

\section{DISCUSSION}

The results of the study showed that roost selection by $P$. giganteus was influenced by tree characteristics such as $\mathrm{dbh}$, height and canopy spread as well as grove size and the ratio of suitable roost trees in the grove. Colony size was also linked to the number of roost trees and grove size. The positive correlation between grove size and colony size suggests that $P$. giganteus prefer to roost in larger groves, providing better protection for their survival and reproduction (Granek 2002, Gulraiz et al. 2015). Although there was substantial variation in the $\mathrm{dbh}$, canopy spread, and height of roost trees, our study indicates these characteristics were important in determining the colony size of $P$. giganteus. Our results support previous findings that bats rely on larger trees for roosting (Vyas \& Upadhyay 2014, Elangovan \& Kumar 2015). It shows that larger groves should be retained to provide roosting habitat for large colonies.

Our findings probably reflect that trees with a large $\mathrm{dbh}$ are long-lasting and resist heavy rain, wind and drought, and trees with a wide canopy spread offer ample surface area for roosting. Further, tall trees offer protection, for instance from human persecution. The larger trees in groves also provide many advantages to the bats like shadow during hot days and suitable conditions for reproduction (Pierson \& Rainey 1992, Granek 2002, Gulraiz et al. 2015). The selection of wider canopy roost trees may also benefit the flying foxes with spacious roosting areas, less competition and facility for reproduction. The large and tall trees offer aerodynamic benefits such as easy take-off and landing to flying foxes (Granek 2002, Gulraiz et al. 2015).

The non-roost dependent factors such as distance of roost from adjacent roads, waterbodies, and human habitations have not significantly influenced the species, while $P$. livingstonii and $P$. alecto preferred to roost adjacent to waterbodies that facilitate humid environment and thermal sensitivity (Palmer \& Woinarski 1999, Granek 2002).

Whilst these results identify the protection of large trees as a priority in protecting these species, more investigations on habitat selection considering their roosting, reproductive and feeding requirements need to be carried out in order to improve our understanding and refine our perception on conservation. Future studies may also investigate their role as a keystone species.

The results of this study suggest that $P$. giganteus selects tall roost trees with a wide canopy which may be important for the survival, social interactions, protection and reproduction of this species. $P$. giganteus is an active pollinator and seed dispersing agent for a number of tree species. Therefore, habitat destruction by tree felling may severely affect the survival of $P$. giganteus and in turn, impact the ecological services they provide. Hence, we recommend the protection of larger trees such as $F$. benghalensis, $F$. racemosa, F. religiosa, F. virens, $M$. indica, S. cumini, $B$. latifolia, D. sissoo, D. regia, A. indica and Eucalyptus sp., particularly the protection of groves of large trees, is incorporated within conservation strategies for the species.

\section{ACKNOWLEDGEMENTS}

The authors would like to place the valuable comments and suggestions of the unknown reviewers which improved the manuscript a lot. The financial assistance of the University Grants Commission, New Delhi, and Uttar Pradesh State Biodiversity Board, Uttar Pradesh through research projects (UGC No. 42-530/2013(SR); UPSBB No: 493/3-4-48/2013) to VE and UGC Fellowship to RK is greatly acknowledged.

\section{REFERENCES}

BARLOW, K. (1999). Expedition field techniques. Bats. ed.: Expedition Advisory Centre of the Royal Geographical Society. London, United Kingdom, 69 pp.

EBY, P. (1991). Seasonal movements of grey-headed flying-foxes, Pteropus poliocephalus (Chiroptera: Pteropodidae), from two maternity camps in northern New South Wales. Wildlife Research, 18(5): 547-559. https://doi.org/10.1071/WR9910547 
ELANGOVAN, V. \& KUMAR, M. (2015). Diversity, Roost Selection and Ecological Importance of the Bats of Uttar Pradesh. International day for biological diversity. Uttar Pradesh State Biodiversity Board, 44-50 pp. http://www. upsbdb.org/pdf/Souvenir2015/ch-7.pdf

FUJITA, M. S. \& TUTTLE, M. D. (1991). Flying foxes (Chiroptera: Pteropodidae): threatened animals of key ecological and economic importance. Conservation Biology, 5(4): 455-463. https://doi.org/10.1111/j.1523-1739.1991. tb00352.x

GRANEK, E. (2002). Conservation of Pteropus livingstonii based on roost site habitat characteristics on Anjouan and Moheli, Comoros Islands. Biological Conservation, 108(1): $\quad 93-100 . \quad h t t p s: / / d o i . o r g / 10.1016 / S 0006-$ 3207(02)00093-9

GULRAIZ, T. L., JAVID, A., MAHMOOD-UL-HASSAN, M., MAQBOOL, A., ASHRAF, S., HUSSAIN, M. \& DAUD, S. (2015). Roost characteristics and habitat preferences of Indian flying fox (Pteropus giganteus) in urban areas of Lahore, Pakistan. Turk J Zool, 39: 388-394. https://doi. org/10.3906/zoo-1401-71

HAHN, M. B., EPSTEIN, J. H., GURLEY, E. S., ISLAM, M. S., LUBY, S. P., DASZAK, P. \& PATZ, J. A. (2014). Roosting behaviour and habitat selection of Pteropus giganteus reveals potential links to Nipah virus epidemiology. Journal of Applied Ecology, 51(2): 376-387. https://doi. org/10.1111/1365-2664.12212

KALCOUNIS-RUPPELL, M. C., PYSLLAKIS, J. M. \& BRIGHAM, R. M. (2005). Tree roost selection by bats: an empirical synthesis using meta-analysis. Wildlife Society Bulletin, 33(3): 1123-1132. https://doi.org/10.2193/00917648(2005)33[1123:TRSBBA]2.0.CO;2

KERTH, G., ALMASI, B., RIBI, N., THIEL, D. \& LÜPOLD, S. (2003). Social interactions among wild female Bechstein's bats (Myotis bechsteinii) living in a maternity colony. Acta Ethol, 5(2): 107-114. https://doi.org/10.1007/s10211003-0075-8

KUNZ, T. H. (1988). Ecological and behavioral methods for the study of bats. ed.: Smithsonian Institution Press. Washington, United States, 533 pp.

KUNZ, T. H. \& LUMSDEN, L. F. (2003). Ecology of cavity and foliage roosting bats. In: Bat Ecology. ed.: The University of Chicago Press. Chicago, Illinois, p.3-89.

LEVERETT, B. \& BERTOLETTE, D. (2015). Measuring guidelines handbook. American Forest. https://www. americanforests.org/wp-content/uploads/2014/12/AFTree-Measuring-Guidelines_LR.pdf

MARIMUTHU, G. (1988). The sacred flying fox of India. Bats Magazine, 6(2): 10-11.
MARKUS, N. \& BLACKSHAW, J. K. (2002). Behaviour of the black flying fox Pteropus alecto: 1. An ethogram of behaviour, and preliminary characterisation of motherinfant interactions. Acta Chiropterologica, 4(2): 137-152. https://doi.org/10.3161/001.004.0203

MEASURING GUIDELINES HANDBOOK (2014). American forests champion trees. Measuring guidelines handbook. https://www.americanforests.org/wp-content/ uploads/2014/12/AF-Tree-Measuring-Guidelines_LR.pdf

MILDENSTEIN, T. L., STIER, S. C., NUEVO-DIEGO, C. E. \& MILLS, L. S. (2005). Habitat selection of endangered and endemic large flying-foxes in Subic Bay, Philippines. Biological Conservation, 126(1): 93-102. https://doi. org/10.1016/j.biocon.2005.05.001

MOLUR, S., SRINIVASULU, C., BATES, P. \& FRANCIS, C. (2008). Pteropus giganteus. The IUCN Red List of Threatened Species. 2008: e.T18725A8511108. https://doi. org/10.2305/IUCN.UK.2008.RLTS.T18725A8511108.en

NEUPANE, K. R., BASNET, K. \& KATUWAL, H. B. (2016). Plight of Indian Flying Fox (Pteropus giganteus) in lowlands of Eastern Nepal. World Journal of Zoology, 11(2): 81-85. https://doi.org/10.5829/idosi.wjz.2016.11.2.10355

PALMER, C. \& WOINARSKI, J. C. Z. (1999). Seasonal roosts and foraging movements of the black flying fox (Pteropus alecto) in the Northern Territory: resource tracking in a landscape mosaic. Wildlife Research, 26(6): 823-838. https://doi.org/10.1071/WR97106

PARRY-JONES, K. A. \& AUGEE, M. L. (1992). Movements of grey-headed flying-foxes (Pteropus poliocephalus) to and from colony site on the central coast of New South Wales. Wildlife Research, 19(3): 331-339. https://doi. org/10.1071/WR9920331

PIERSON, E. D. \& RAINEY, W. E. (1992). The biology of flying foxes of the genus Pteropus: a review. In: Pacific island flying foxes: proceedings of an international conservation conference. ed.: Wilson, D. E. \& Graham, G. L. US Fish and Wildlife Service Biological Report 90(23), US Department of the Interior, Fish and Wildlife Service. Washington, United States, p.1-17.

SHILTON, L. A., ALTRINGHAM, J. D., COMPTON, S. G. \& WHITTAKER, R. J. (1999). Old World fruit bats can be longdistance seed dispersers through extended retention of viable seeds in the gut. Proc. R. Soc. Lond. B., 266(1416): 219-223. https://doi.org/10.1098/rspb.1999.0625

VYAS, R. \& UPADHYAY, K. (2014). Study of the Indian Flying Fox (Pteropus giganteus) Colonies of Jambughoda Wildlife Sanctuary, Gujarat, India: Record of largest roosting congregation at Targol. Small Mammal Mail, 6(1): 2-8. 